\title{
15 \\ A SUPREME COURT OR A CONSTITUTIONAL JIRGA?
}

\author{
Moeen Cheema
}

This chapter investigates the role that the Supreme Court has played in the context of an increasing democratic deficit and the emergence of what is being widely referred to as a civilmilitary 'hybrid' regime in Pakistan. It looks closely at high-profile constitutional cases decided before and after the 2018 parliamentary elections and the resulting transfer of power to the current Pakistan Tehrik-e-Insaaf (PTI) government led by Prime Minister Imran Khan. These include cases in which former Prime Minister Nawaz Sharif was disqualified from being a member of parliament for life, and from formally heading his political party, an outcome which significantly undermined his party's prospects in the 2018 elections. In another notable case, the Supreme Court heard a challenge to the extension of the incumbent Army Chief's tenure, but rather than laying out clear rules for such a scenario referred the matter to parliament, which inadvertently paved the way for greater military intervention in the political process. In a more recent case, the apex court reviewed the constitutionality of the proceedings for the removal of a Supreme Court judge known for stern critique of the military's involvement in politics. This case, which is still making headlines at the time of the writing of this chapter, has resulted in visible divisions within the court itself and tarnished the reputation of the judiciary, leaving it a less credible arbiter of constitutional controversies.

The chapter argues that in such cases involving matters of high constitutional law and politics, the apex court has developed a method to temporarily reduce the political and interinstitutional tensions by mediating between the various power centres and reaching intermediate outcomes, rather than principled peremptory decisions. As such, the court acts more like a proverbial jirga (council of elders in customary dispute resolution) seeking a negotiated settlement between the parties than a forum of legal adjudication. While such judicial intervention temporarily reduces the political strains, it ultimately enables the military-backed hybrid regime to assert its dominance under the cover of judicial oversight, contributing to autocratization in Pakistan. These cases and crises litigated before the Supreme Court are mere symptoms of a chronic ailment. The prospects of meaningful democracy in Pakistan are undermined by structural defects that no institution or political agent can remedy in the short term. At this stage it appears unlikely that the entire democratic set-up will be dispensed with through yet another military coup. Neither does it appear likely that mere continuity of the political dispensation will improve Pakistan's prospects of becoming a more democratic nation. The key 
institutions - governments, opposition political parties, courts and the military - remain firmly entrenched in their positions and seem determined to guard their respective turfs rather than negotiating long-term solutions to the challenges of corruption, electoral malpractices, devolution and consensus-based policy-making on administrative and legal reform that might lead to a more stable and democratic Pakistan. The judiciary could play a significant role in such an environment in terms of setting firm constitutional rules for the game of politics. However, its strategy of mediating political crises and finding short-term compromises has exacerbated political divisions rather than improving the democratic process. Furthermore, the Supreme Court is increasingly looking like a divided house itself.

\section{The Panama case and electoral engineering}

Pakistan's previous government at the federal level was formed by the Pakistan Muslim League (PML-N) in 2013 and led by Prime Minister Nawaz Sharif for an expected five-year parliamentary term. The first two years of the party's rule were dogged by claims of large-scale electoral rigging by the most vocal opposition party, the PTI, led by cricketer-turned-politician Imran Khan (Cheema, M 2016, pp. 76-8). After a protracted political crisis, the controversy temporarily died down when both parties agreed to the formation of a judicial commission to investigate the allegations. While the judicial commission exonerated the ruling PML-N on the count of organized rigging, it nonetheless identified serious failings in the electoral process (Cheema, M 2016, pp. 78-9). A parliamentary committee formed as a result of the crisis failed to develop a consensus on electoral reforms and the issue was likely to reignite with a vengeance as the 2018 elections approached.

The PML-N government enjoyed barely a year of stability in the aftermath of the PTI protest movement when in April 2016 the International Consortium of Investigative Journalists released leaked documents of a Panama-based law firm. The 'Panama Papers' revealed several offshore companies owned by Prime Minister Nawaz Sharif's family and proved their ownership of high-end properties in London (Cheema, H 2016). The Sharif family has been in the business of politics and power either in the centre or Punjab, Pakistan's largest province, for much of the last three decades. There had been allegations of corruption, money-laundering and tax evasion during every term that the party has won elected office, especially during Nawaz Sharif's two terms as Prime Minister in the 1990s. However, the Sharifs and their party managed to avoid both political fallout and judicial scrutiny of corruption charges. In contrast to the PML-N, the Pakistan People's Party (PPP), which formed the government from 2008 to 2013, was dogged by high profile corruption scandals and intense judicial review by the Supreme Court. The PML-N had provided unwavering and visible public support to the court's accountability drive including the decision to disqualify former Prime Minister Gilani for failure to institute corruption charges against President Zardari, also dating back to the 1990s (Mahmood 2012). Unlike the PPP's judicial ordeal, however, the corruption and moneylaundering allegations against the Sharifs appeared to have become past and closed transactions, a matter of history, until the release of the Panama Papers.

Despite the demands from the PTI for the formation of another judicial commission to investigate corruption and money-laundering allegations released in the Panama Papers, neither the government nor the court relented. In August 2016, Imran Khan, who has adopted an anticorruption platform as the main charter of his party, decided to take the matter to the Supreme Court under Article 184(3) of the Constitution, which provides for the 'Original Jurisdiction' of the court. In such cases, the court can directly take up matters of "public importance with reference to the enforcement of any of the Fundamental Rights" including important questions 
of constitutional interpretation. After months of regular hearings which received almost daily coverage in the national media, the five-member bench issued its first judgment in April 2017 (Imran Khan v. Nawaz Sharif, PLD 265). All five members of the bench appeared to agree that Prime Minister Nawaz Sharif and his family had failed to satisfy the court regarding the source of their immense wealth, or to provide a satisfactory account of when and how the properties in London were purchased. The respondents' explanations seemed evasive and had shifted dramatically over the course of the proceedings. There was no proof of any bank transactions or any financial evidence of when and how the properties were purchased.

Nonetheless, the case raised challenging issues regarding the interpretation of the provisions on disqualification of members of parliament pursuant to which the removal of the Prime Minister was sought. Article 62(1)(f) of the Constitution states that a person "shall not be qualified to be elected or chosen as a member of Majlis-e-Shoora (Parliament) unless ... (f) he is sagacious, righteous, non-profligate, honest and ameen, there being no declaration to the contrary by a court of law." The question before the court was whether it could issue such a declaration under its Original Jurisdiction and disqualify the Prime Minister in the same proceedings based on the material on the record. The respondents argued that the court could only disqualify a member of parliament if there had been a prior conviction or judgment by a court of competent jurisdiction for tax evasion, money-laundering, possession of wealth beyond known means, or a judicially proven misdeclaration of assets in the nomination forms filed as a candidate at the time of the elections (Cheema, M 2018). It is on this crucial question that the bench split with only two judges holding that Nawaz Sharif was disqualified from being a member of parliament and hence the Prime Minister for lack of integrity and financial probity. Justice Khosa, who was scheduled to be the next Chief Justice, wrote a lengthy and scathing opinion arguing that there was prima facie evidence of corrupt practices by Prime Minister Nawaz Sharif (Imran Khan v. Nawaz Sharif, PLD 265). Since the Prime Minister and his family were the only people who held complete knowledge of the transactions the onus was on the respondents to provide such a 'money trail.'

The majority of the bench, however, took a different stance on the issue of jurisdiction under Article 184(3). While also noting the glaring gaps in the Sharif family's explanation of their financial dealings, nonetheless, they argued that the court could not disqualify a member of parliament in the absence of "admitted facts or indisputable documentary evidence" (Cheema, M 2018). Nonetheless, all three judges forming the majority in this phase of the case directed the creation of a Joint Investigation Team (JIT) to probe the allegations against the respondents and produce a report within sixty days after which the Supreme Court may again take up the matter. While the government initially expressed joyous relief at the Supreme Court's interim order, the composition and the conduct of the JIT caused anxiety amongst ministerial ranks. The JIT not only included senior officials from a range of civilian agencies chosen by the court but also representatives of the military's intelligence services. The majority justified the inclusion of the military intelligence officials on the grounds that all civilian investigation agencies appeared to be under the control or influence of the incumbent Prime Minister and had refused to investigate the allegations (Cheema, M 2018).

In July 2017, the JIT presented a voluminous report to the 'Implementation Bench' comprising the three judges who had directed the formation of the JIT (Dawn, 11 July 2017). The JIT's report unveiled extensive offshore holdings and businesses of the Sharif family well beyond what had surfaced in the Panama Papers. The JIT report also provided considerable evidence that the stance of the respondents on several issues and some of the documents furnished by them to the court were patently false and fabricated. The three judges who had directed the formation of the JIT focused almost exclusively on one piece of information in the dossier 
which was admitted by the Prime Minister. Nawaz Sharif had remained the chairman of the board of a UAE company named Capital FZE for six and a half years leading up to the 2013 elections and was entitled to receive a salary. This position was used to obtain a permit to work and live in the UAE. Nawaz Sharif's lawyer admitted before the bench that the salary had accrued to the respondent as chairman of the board, but he had not withdrawn it at any stage until the company was dissolved in early 2013. The bench used this admission, and relying on dictionary definitions, held that accrued receivables were assets which were required to be declared by a candidate for election. Since the Prime Minister had failed to disclose this asset in his nomination papers at the time of the 2013 elections, he was disqualified from being a member of parliament for life, and hence this deposed him from office (Imran Khan v. Nawaz Sharif, PLD 692).

Of the plethora of material included in the JIT report, the accrued but un-withdrawn salary from Capital FZE was arguably among the weakest evidence of financial impropriety against the disqualified Prime Minister. Even though the five-member bench ultimately reached a unanimous decision after a convoluted two-stage process, the majority's reliance on accrued salary as undeclared asset provided both sides of the political divide with a basis to strengthen their respective narratives. The PML-N criticized the court's decision as biased and legally incorrect, and several of its most vocal members were charged with and some were also convicted of contempt of court for such criticism. The Supreme Court's decision in the Panama case, and the resulting trial of Nawaz Sharif before an Accountability Court on corruption charges and possession of assets beyond known means, strengthened the opposition PTI's narrative as well as electoral prospects. The ruling PML-N as well as the PPP also claimed that pre-election rigging was also in play, whereby the military and its intelligence agency (ISI) were involved in the business of persuading 'electable' politicians and some minor parties to join the PTI.

There were again complaints of significant poll day rigging in the 2018 elections (Mir 2018). The elections resulted in a victory of sorts for the PTI as it emerged as the largest party in the National Assembly and in the provincial assembly of Punjab. However, it lacked a clear majority and needed the support of an array of minor parties and independently elected candidates to form governments at the federal level and in Punjab. There were also rumours that the formation of this seemingly fragile coalition had been facilitated by the military, providing the basis of the narrative that Imran Khan's elected government was merely the cover for what was in essence a civil-military hybrid regime. This accusation against the PTI-led elected governments at the federal and provincial levels has only been strengthened by subsequent controversies, some of which ended up before the Supreme Court for adjudication.

\section{Extension of Army Chief's tenure and parliamentary complicity}

Despite the complaints of the opposition and allegations of electoral manipulation, the PTI governments at the centre and in Punjab appeared to be relatively stable. The opposition by and large accepted the results and unlike in the aftermath of the 2013 elections grudgingly conceded the outcome of the 2018 elections. While there were progressively increasing concerns about the capacity of the PTI to institute effective governance as the party lacked previous experience of ruling, the opposition initially proclaimed that it would provide it with the space to rule for the maximum term of five years as stipulated in the Constitution. However, as the PTI began an increasingly assertive and relentless campaign of accountability for political corruption against major opposition figures, the working relationship between the government and opposition 
in the legislative assemblies began to visibly deteriorate (Rehman 2020). The public debate between the government and the opposition became increasingly personalized and vitriolic, and political fragmentation in the country appeared to be reaching heights not experienced since the 1990s.

In November 2019, the incumbent Army Chief's three-year term was due to expire. The retirement of the Chief of Army Staff (COAS) and the selection of his successor has historically been a politically sensitive moment. In August 2019, in order to pre-empt any speculation as to the matter, the PTI government attempted to grant General Qamar Javed Bajwa a threeyear extension in his tenure as the COAS arguing that a difficult regional security situation required continuity in his command of the armed forces. A relatively unknown petitioner filed a challenge to the extension of tenure before the Supreme Court under its Original Jurisdiction (Jurisdiction Foundation, PLD 52). However, the petitioner refused to pursue the case but the court, nonetheless, continued the proceedings on the basis that a public law case brought under its Original Jurisdiction does not automatically cease if the petitioner seeks to withdraw it. Effectively, the court thus turned this petition into a suo motu case, that is, one initiated by the court itself. At issue in the initial proceedings of the case were the legality of the notification issued by the government purporting to grant an extension in the COAS' tenure. There were several irregularities in the issuance of the notification itself, which represented confusion on the part of the government as to the appropriate process. First Prime Minister Imran Khan had himself issued the initial notification of extension in tenure, then immediately realized that under Article 243 of the Constitution the power of appointment rests with the President so the Prime Minister's office sent a summary to him recommending the re-appointment of the COAS who instantly approved it. The very next day, the government recognized that the Prime Minister's recommendation needed prior approval by the Cabinet, which was sought post hoc through circulation of the draft summary rather than through a Cabinet meeting (Jurist Foundation, PLD 1).

As the court proceedings unfolded, a very peculiar legal problem began to crystallize. Although the tenures of Army Chiefs had been extended on several occasions in Pakistan's history, there was no legal framework governing the tenure and terms of service of the Army Chief. The Army Act, 1952 which had been framed by Pakistan's first Constituent Assembly pre-dated all three of Pakistan's constitutions (respectively framed in 1956, 1962 and 1973). After considerable vacillation, the government and the COAS' lawyers settled on the argument that in the absence of any relevant legal provisions in the Army Act, Article 243(3)(b) of the Constitution - which granted the President the power to appoint the Army Chief on the advice of the Prime Minister - was effectively a self-executing provision, that is, one which can be given effect to without the aid of legislation. The government also argued that there existed an unwritten convention that the tenure of the COAS was initially for three years and could be extended for another term of any duration under Article 243 (Jurist Foundation, PLD 1). The court had two clear legal options before it. It could have accepted the government's position that Article 243 was a self-executing position and the appointment, re-appointment, and extension of tenures of the COAS were completely the President's prerogative, subject to the advice of the Prime Minister and Cabinet. While this position would have assisted the government in the instant case and legalized the problematic practice of extending Army Chiefs' tenures, it would have juridically established the primacy of civilian governments in the appointments of the COAS, historically a matter fraught with tensions between civil and military leaderships. Alternatively, the court could have taken a categorical position against extensions of tenure of Army Chiefs and held that since Article 243 is not a self-executing constitutional provision, in 
the absence of any relevant provision in the Army Act enabling the extension of the COAS' tenure such a purported extension was illegal.

Instead, the court chose a middle ground that temporarily placated both sides. The court delved into the constitutional history of Article 243 and observed that Article 40 of the 1956 Constitution had stated that until "Parliament makes provision by law in that behalf, the President shall have the power ... to appoint Commanders-in-Chief of the Army." The court interpreted this provision as transitory, and given that the Army Act, 1952 was already in existence, an expression of the assertion that the Army Act needed to be substituted or amended to provide for more comprehensive regulation of the armed forces (Jurist Foundation, PLD 1). Similarly, the court analyzed comparable provisions in the 1962 and the original form of the 1973 constitutions, which provided for the command of the armed forces and the power to appoint services chiefs to be vested in the President "subject to law" and observed with some surprise and consternation that no such law had been passed since the promulgation of the 1973 Constitution. The court subtly glossed over the fact that contrary to its interpretation of Article 40 of the 1956 Constitution, the phrase "subject to law" could be interpreted to mean that the framers of the 1962 and 1973 constitutions proceeded upon the assumption that such law already existed in the form of the 1952 Army Act, evidenced further by the absence of any attempts to substitute or significantly amend it. Nonetheless, the court proceeded to interpret the requirement of raising and maintaining the armed services "subject to law" under Article 243 of the Constitution to hold that legislation governing the tenure, retirement age, and the process for the extension of service of the Army Chief needed to be passed by the parliament. In an exercise of "judicial restraint" and enabling a compromise between the government and the opposition, the court effectively granted an interim six-month extension to the COAS' tenure during which parliament may pass legislation to regulate the services chiefs' tenures on a permanent basis (Jurist Foundation, PLD 1).

Such legislation required the support of the opposition as the government lacked a majority in the Senate, the upper house of parliament. However, despite the challenging parliamentary equation, and despite mutterings of discontent from the opposition, the legislation was speedily passed in January 2020 validating the extension in the COAS' tenure. Contrary to the seemingly broader import of the Supreme Court's judgment, the Act focused exclusively on the President's power to appoint, reappoint and extend the tenures of the services chiefs. It clarified that the initial appointment of the COAS will be for a term of three years, which may be extended for an initial period of up to three years at the discretion of the President upon the advice of the Prime Minister (Pakistan Army (Amendment) Act, 2020). The Act also provided that the maximum retirement age of the COAS will be 64 years. The ease with which the Act was rushed through the parliament gave credence to rumours of backroom dealings between the military establishment and the two major opposition parties, the PML-N and the PPP. Such claims of accommodation between the military and the opposition gained further strength when prior to its enactment Nawaz Sharif was granted bail in the corruption cases against him on medical grounds and allowed by the government and the courts to travel abroad to seek treatment for an allegedly serious immune disorder.

Since his departure to the UK, no evidence has been forthcoming of Nawaz Sharif's continuing serious ailment or of any medical treatment he may have received in that regard. As such, while the Supreme Court's decision nominally resulted in upholding the parliament's right to legislate on military affairs, as a matter of political reality it only showed that not only the government but also major opposition parties are susceptible to the military's influence as and when the need for their complicity arises. Furthermore, protracted corruption investigations and trials against virtually all significant opposition leaders thus provide both the government and 
the military with considerable leverage over the opposition and have strengthened the narrative that the hybrid regime uses accountability processes for political manipulation.

\section{Judicial accountability and a fractured Supreme Court}

In May 2019, the President filed a reference against Justice Qazi Faez Isa, a sitting judge of the Supreme Court, before the Supreme Judicial Council alleging the ownership of undeclared and unaccounted-for foreign properties by his spouse and children. The Supreme Judicial Council (SJC) - comprising the Chief Justice, the two most senior judges of the Supreme Court, and the two most senior Chief Justices of the provincial High Courts - issued a show cause notice to Justice Isa commencing proceedings under Article 209 which provides the exclusive mechanism for the scrutiny and removal of a judge for misconduct. Justice Isa responded to the show cause notice, and also filed a petition challenging the reference under the Original Jurisdiction of the apex court arguing that the presidential reference to the SJC was mala fide (i.e., issued in bad faith) and had been initiated to discipline him for certain judgments in which he had criticized the involvement of the military in politics (Justice Isa, PLD 1). The case acquired additional significance because Justice Isa is scheduled to become the Chief Justice in September 2023, coinciding with the end of the current parliamentary term and the resulting elections if the presidential reference against him were quashed. There were a number of legal defects manifest in the record and the preparation of the reference. As such, the court could have simply quashed the reference and ended the matter at that point, of course leaving open the possibility for the government to prepare a more thorough reference if it wished to do so at some political cost. Conversely, the court could have held that since the SJC has already taken cognizance of the matter, that is the preferable forum.

Instead, once again, the court chose an intermediate form of action and proceeded with hearings in the case for approximately ten months before a ten-member full bench (Justice Isa, PLD 1). In the process, regular coverage of the proceedings in the media caused considerable damage to the court's standing for amongst other things Justice Isa objected to the original composition of the bench as it included two judges who would stand to benefit: one would become the Chief Justice of the Supreme Court for a short duration; the other would have his tenure extended if Justice Isa were to be removed from office. Both judges recused themselves from the bench under protest as their impartiality had been implicitly impugned by Justice Isa's request. The petitioners, which included not just Justice Isa but also an array of senior lawyers and representatives of bar associations, had argued that the presidential reference had been motivated by malice and was designed to undermine the independence of the judiciary. In June 2020, all ten members of the bench held the reference to be a nullity (Justice Isa, PLD 346). However, the majority judgment, in which seven members of the bench joined, declared the reference to be mala fide in law as there were several grave errors of law in the preparation of the reference which represented a blatant disregard of the law, but there was no malice in fact on the part of the President or the government.

The errors in the preparation of the reference included the fact that it was not the President who had initiated the investigation upon the advice of the Prime Minister as required by the Constitution, but instead the Law Minister had authorized the Asset Recovery Unit attached to the Prime Minister's office to conduct the investigation upon the supposed application of a relatively little known and dubious informant. The majority also observed that the basis of the reference was essentially a tax matter, but unsubstantiated allegations of moneylaundering had been included in the reference. The President was required to act on the 
advice of the Prime Minister but in the present context was also required to seek independent advice and exercise his own judgment prior to forwarding the reference to the SJC, which he failed to do. As such, the presidential reference to the SJC, and consequently the SJC's show cause notice to Justice Isa, were quashed. However, at the same time, the seven-member majority of the bench sent the matter to the Federal Bureau of Revenue (FBR) to investigate the allegations contained in the reference and issue notices to Justice Isa's spouse and children under the relevant tax laws "to offer an explanation regarding the nature and source of the funds (Justice Isa, PLD 1)." The FBR was also directed to present a report to the SJC, leaving open the possibility that a new reference may be initiated by the SJC suo motu in case of adverse findings against Justice Isa in the FBR report. The court thus temporarily diffused the crisis, chastising the government for the manner in which the reference was filed, but also partially substantiated the allegation leaving the proverbial sword of Damocles hanging over the future Chief Justice.

Contrary to the three judges in the minority who insisted on the end of all proceedings against Justice Isa in the quashing of the reference, the majority insisted that a perception of the accountability of the judiciary also needed to be maintained (Justice Isa, PLD 1). Since the ownership of three properties in London by the spouse and children of Justice Isa, even though financially independent, had been admitted the source of the funds and the mode of their transfer needed to be investigated by the tax authorities. This was necessitated by the definition of 'misconduct' under Article 209 of the Constitution which, according to the seven-member majority, included both professional and private actions, and not just conduct related to the performance of official/judicial functions. Furthermore, the judicial code of conduct requires judges to "avoid litigation and to be diligent in their financial affairs to minimise the chance of any embarrassment in the performance of their functions (Justice Isa, PLD 1)." Given that the close family of a judge enjoy many of the incidental perks and privileges of their office, it is incumbent upon the family members to also demonstrate probity and discretion in their affairs. As such, it is also incumbent upon judges to be reasonably aware of their family's financial affairs and they cannot thus simply take the plea that their close family are financially independent. As noted above, although the majority of the bench sought to balance the need to protect judicial independence from interference by the executive with transparency in judicial accountability, the end result was a prolongation of the crisis which has left not only the public perception of the judiciary tarnished but has also led to deepening divisions in the Supreme Court.

In a review of the Supreme Court's decision, Justice Isa notably and in an unprecedented manner decided to argue his own case before his colleagues on the bench. In protracted proceedings, which are rare in review cases as the court is only empowered to reassess the legality of its original decision, Justice Isa not only levelled serious allegations of persecution by the government at the behest of the military command for criticizing the military's role in politics, but also criticized members of the apex court for failing to safeguard judicial independence. Such public criticism of the judiciary from an apex court judge arguing his own case has taken its toll on the Supreme Court's reputation, and divisions within the court over Justice Isa's case have also become manifest. Although the bench decided by a narrow majority of $6: 4$ judges to quash all proceedings against Justice Isa, the court will be the ultimate loser. As Justice Isa has been absolved of charges of misconduct against him without providing the 'money trail' or chain of transactions in the purchase of foreign properties by his family, parallels with Nawaz Sharif's case will be inevitable. The critics of the court will accuse the judiciary of setting a different standard of probity for judges than was set for elected politicians in Nawaz Sharif's 
disqualification case. This would also strengthen the PML-N's narrative that Nawaz Sharif's disqualification was in error of law. On the other hand, when Justice Isa ascends to the office of the Chief Justice, his impartiality on issues relating to the PTI and the current government will remain under a cloud.

\section{Conclusion}

As noted in the introduction, and highlighted in this chapter, the Supreme Court has become the arena for resolution of high profile and potentially destabilizing constitutional and political controversies. Instead of laying down clear constitutional principles and bright line rules governing the conduct of governance, politics, and institutional powers and parameters, the apex court has repeatedly sought to act as a mediator and found various devices to temporarily diffuse the underlying political tensions.

In the Panama case, the court failed to avail the opportunity to lay the ground rules on how corruption charges against ruling politicians and allegations of financial impropriety ought to be dealt with. Instead, the majority on the bench found an intermediate solution by creating a Joint Investigation Team (JIT) that may engage in fact-finding and enable the court to determine the probity of the allegations against former Prime Minister Nawaz Sharif. The outcome was a decision that was principally muddled and has given an extended lease of life to political fragmentation. In the Army Chief's tenure case, the court again diffused the tensions in the interim by referring the matter to the parliament rather than reaching a clear and precise legal formulation, resulting in the extension of the controversy and paving the way for the military's enhanced involvement in parliamentary politics. Finally, in Justice Isa's case, rather than deciding the matter on clear constitutional grounds by either completely quashing the reference or letting the Supreme Judicial Council (SJC) conduct its proceedings, the court reached a compromised interim solution of referring the matter to the tax authorities. This has only resulted in further controversy with protracted proceedings which have cast a shadow over the court's credibility as an independent and impartial arbiter of constitutional controversies.

In a constitutional scheme such as Pakistan's, given the contexts of increased polarization and the heightened role of the military in the political process, an independent and credible judiciary is needed to act as a check on increasing autocratization and reduce controversies that serve to destabilize the fragile democratic system. Not only has the court failed in that task, its mediatory approach has only served to enhance the dialectic of autocratization and destabilization, and the judiciary itself is now under strain as a result of that failure.

\section{Bibliography}

Cheema, Hasham, 2016, “How Pakistan's Panama Papers probe unfolded”, Dawn, 3 April.

Cheema, Moeen, 2016, “'Election disputes' or disputed elections? Judicial (non-)review of the electoral process in Pakistan” in P J Yap (ed.), Judicial Review of Elections in Asia, London: Routledge.

Cheema, Moeen, 2018, "Pakistan: The state of liberal democracy", International Journal of Constitutional Law, vol. 16, no. 2, pp. 635-42.

Mahmood, Amjad, 2012, "Nawaz threatens 'all options' to unseat Gilani”, Dawn, 27 April.

Mir, Asfandyar, 2018, “What just happened in Pakistan's election? And what happens next?”, Washington Post, 26 July.

Pakistan Army (Amendment) Act, 2020. Government of Pakistan.

"Read full text of Panama Papers JIT report", Dawn, 11 July 2017.

Rehman, Abdul, 2020, "Pakistan: How 'Accountability' Became a Tool for Political Oppression”, The Diplomat, 13 February. 


\section{Moeen Cheema}

\section{Cases}

Imran Ahmad Khan Niazi v. Mian Muhammad Nawaz Sharif, Prime Minister of Pakistan, PLD 2017 SC 265 Imran Ahmad Khan Niazi v. Mian Muhammad Nawaz Sharif, Prime Minister of Pakistan, PLD 2017 SC 692 The Jurist Foundation v. Federal Government, PLD 2020 SC 1

The Jurist Foundation v. Federal Government, PLD 2020 SC 52

Justice Qazi Faez Isa v. The President of Pakistan, PLD 2020 SC 346

Justice Qazi Faez Isa v. The President of Pakistan, PLD 2021 SC 1 